\title{
Post-graduate Education in Traditional and Non Conventional Medicine: Italy poised between National Guidelines and Regional Variants
}

\author{
Tognetti Bordogna $\mathbf{M}^{1,2}$, Gentiluomo $\mathbf{A}^{2}$ and Roberti di Sarsina $\mathbf{P}^{2,3 *}$
}

${ }^{1}$ Department of Sociology and Social Research, University of Milano-Bicocca, Milan, Italy

${ }^{2}$ Observatory and Methods for Health, Department of Sociology and Social Research, University of Milano-Bicocca, Milan, Italy

${ }^{3}$ Expert for Non Conventional Medicine, High Council of Health, Ministry of Health, Italy

\begin{abstract}
The present article completes our research which first part has been published in AIM, being the very first survey about Education in Traditional and Unconventional Medicine within the Italian Schools of Medicine. The present data also go into the choice of titles for the various education options, our article considering both the undergraduate and post graduate education programmes in this field and deals with also the particular regional organization of Italian Regions in the field of Health which extends to Upgrade Courses, shows a growing interest by Italian universities centres even if where regional decision-makers are not explicitly in favour of TCAM. The article also explores the extent of regional difference and the indirect contribution the Regions seem to have made to the TCAM education courses on offer.
\end{abstract}

Keywords: Traditional Medicine (TM); Non Conventional Medicine (NCM); Complementary and Alternative Medicine (CAM); Education; Italy; University; Faculties; School of Medicine; National Health System; Regional Health Systems

\section{Foreword}

The present article is based on research data collected in the course of the first edition of the Master Degree in "Health Systems, Traditional and Non Conventional Medicine" held by the University of MilanoBicocca $[1,2]$.

The research focused on post-graduate education opportunities in Traditional and Non-Conventional Medicine (TM/NCM) or Complementary and Alternative Medicine (CAM) provided by Italian universities. The field was deliberately narrowed to the area of TM/ NCM/CAM education since the University alone is legally responsible for offering qualifications and vetting training courses, given its legal control over training operations. The Faculties considered were Medicine, Veterinary Science and Pharmacy. It must be remembered that these Faculties include various degree courses: the Single-Cycle Degree Course in Medicine, 3-year degrees in health professions (Nursing Science, Obstetrics, Physiotherapy, Dentistry), herb sciences, and various others.

What caught our interest in this research is that, regardless of the official position on CAM education taken by the Permanent Conference of Deans of Medicine Degree Courses (CPPCLM),-opposition to CAM being introduced in the six-year degree course in medicine $[3,4]$, various universities have invoked the principle of didactic freedom and independence guaranteed by art.33 of the Italian constitution and are showing keen interest in training of this kind.

From the research collected, this article will show how the actual line taken by the various universities challenges the official position of the deans' conference, and how the exact forms of training offered differ from region to region.

Many factors have inclined certain Italian universities to invest in training in these anthropological traditions of healing. First, there is the economic incentive of enrolment, which is here distinctly higher than figures for traditional degree courses. Secondly, such training lends itself, as we shall see, to some differentiation, so that centres can choose their position within the university market. Third, there is the impact of such training in terms of visibility and prestige. Fourth is the opportunity of setting up partnerships and collaboration with private concerns interested in legitimising TM/NCM/CAM. Fifth there is consistency with their own education policy [5]. Lastly, pressure from territorial bodies, especially the regions, which are more or less overtly nudging the universities in this direction [6]. The regions are, of course, in charge of Regional Health Systems, while other aspirations across the country lend their weight to such training (e.g. manufacturers of certain derivatives, services dispensing TM/NCM, etc.) $[7,8]$.

In a scenario of change such as we see with TM and NCM in Italy at least, it seems evident that the University as guarantor of professional profiles must take every step $[9,10]$ to safeguard the public who are flocking to Traditional and Non Conventional Medicines [11-14].

Among the factors behind the mounting recourse to TM/NCM are: the more symmetrical relationship it offers between doctor and patient; the individual's growing sense of responsibility for his/her health, and desire to choose and decide on therapy in the first person [15-17]; a changing representation of disease and healing $[18,19]$; styles of communication and relationship that respect the patient's past experience more sensitively $[20,21]$ than biomedicine; increasing immigration into Italy and, as a result, the opportunity for newcomers to resort to their own forms of knowledge and health practice. Last but not least, "the slow advance of such forms of medicine within the options provided by some Italian Regional Health Systems and

*Corresponding author: Paolo Roberti di Sarsina, Expert for Non Conventional Medicine, High Council of Health, Ministry of Health, Siepelunga 36/12, 40141 Bologna, Italy, Tel: 393358029638; Fax: 39051442039; E-mail: paolo.robertidisarsina@unimib.it

Received September 28, 2013; Accepted November 01, 2013; Published November 04, 2013

Citation: Tognetti Bordogna M, Gentiluomo A, Roberti di Sarsina P (2013) Postgraduate Education in Traditional and Non Conventional Medicine: Italy poised between National Guidelines and Regional Variants. Altern Integ Med 2: 143 doi:10.4172/2327-5162.1000143

Copyright: ( 2013 Tognetti Bordogna M, et al. This is an open-access article distributed under the terms of the Creative Commons Attribution License, which permits unrestricted use, distribution, and reproduction in any medium, provided the original author and source are credited. 
Citation: Tognetti Bordogna M, Gentiluomo A, Roberti di Sarsina P (2013) Post-graduate Education in Traditional and Non Conventional Medicine: Italy poised between National Guidelines and Regional Variants. Altern Integ Med 2: 143. doi:10.4172/2327-5162.1000143

their new drug/economic set-up, as shaped by Italy's current health management requirements" $[5,14]$.

The Italian Health System is $[22,23]$ going through a phase of radical redefinition, the upshot of which is still hard to describe- though the more pessimistic are forecasting the end of public health. What is more, the paradigm of Biomedicine and Evidence-based Medicine which it stems from, though markedly successful for acute pathology [17], is now being impinged on by Person Centre Medicine which is more attentive to individual healthcare needs $[21,24,25]$. This runs counter to the trend for advanced screening and standard procedures which have not always delivered the expected outcome; indeed, some hypertechnical forms of medical intervention have only broadened the gap between patients and medical professionals.

In this changing scenario Traditional and Non Conventional Medicine point the way to a new health approach: they are cheaper than biomedicine yet none the less effective against much pathology; they more closely meet the patient's needs and are legitimated by ageold health knowledge, as well as by research which, as in the case of acupuncture-treated headache, displays equal if not better results than treatment by conventional medicine $[19,26,27]$.

\section{Research Methods}

As mentioned, the universe of reference is the Faculties of Medicine, Veterinary Science and Pharmacy. In the first case our research covered 37 public universities and totalled 40 degree courses (Turin having two Faculties and Roma having three); 3 private universities (Campus Biomedico; University Cattolica del Sacro Cuore of Rome and Campobasso; University San Raffaele Vita e Salute); and the University Foundation of Mantova which, in its Medical Faculty, falls under University of Brescia and University of Milano.

In addition we cover 14 faculties of Veterinary Science and 28 Faculties of Pharmacy.

For our update on Medical Faculty training options we used a semi-structured questionnaire, sent by e-mail, comprising 8 questions designed to elicit the range of TM/NCM options proposed by the Faculty at its various training levels (Elective Courses, Masters Levels I and II, Postgraduate Completion Courses, Higher Education Courses, Post-Graduate Specialisation Schools, PhDs, other forms of training like seminars). For each course we sought to know the number of training credits, the amount of theoretical and practical hours of teaching, the name of the reference person and the programme. The questionnaire also extended to any research projects promoted and the presence of any structured TM/NCM teaching staff.

For information on Veterinary and Pharmacy Faculties we analysed the university web portals. This information channel was also used to supplement the Medical Faculty picture, since only $38.6 \%$ of Medical Faculties responded to the survey by sending back the questionnaire [5].

Our research covered all post-graduate courses, of academic year 2011-2012, making clear reference to CAM in their titles. Hence postgraduate courses such as University of Parma's "Low Dose Medicine", University of Pescara-Chieti's "Functional Biological Medicine", University of Pisa's "Hydrokinesitherapy", "Manual Therapy" and "Anatomy and Fascia Manipulation", University of Padova's "Manual Therapy and Muscle-Skeleton Rehabilitation", University of Bologna's "Psycho-Neuro-Endocrine-Immunology" and Torino's "Chiara Colombo" Territorial Pharmacy were not included in the survey, even though some of them were heavily CAM-oriented.

\section{TM/NCM Education Options in Italy}

Despite the official position of the Medical Deans' Conference, there is already a history of Italian Medical Schools opening their doors to $\mathrm{TM} / \mathrm{NCM}$ in the name of their above-mentioned didactic freedom and independence. Analysis of the various university websites shows university training courses, quite separate in starting date, being set up by not exclusively medical academe in a spirit of far-sighted broadmindedness about traditional forms of healthcare.

In the academic year 1997-1998 the University of Milano offered the first edition of an Upgrade Course in "Acupuncture, Stress and Related Pathology"; the same year the University of Tuscia (Viterbo) first launched an Upgrade Course in "Phytotherapy and Medicinal Herbs". Two years later it inaugurated an Upgrade Course in "clinical Phytotherapy" to which the foregoing course was by way of preparation.

In the academic year 2004-2005 University of Napoli "Federico II" first activated its Masters in "Osteopathy" providing technical and scientific knowledge designed as a proper training in this CAM field.

The first CAM Higher Training Course (CAF), called "Integrating Conventional and Non Conventional Knowledge in Medicine. Analysing and comparing anthropological and philosophical with physical and clinical knowledge in various healthcare systems", was launched in 2006-2007 by the University of Bologna Faculty of Medicine in collaboration with the other faculties.

On May 9th 2007 the University of Catania ran a seminar on "Phytotherapy and science: pharmacological and clinical effectiveness of vegetable remedies". In the academic year 2007-2008, after a successful first edition, the University of Bologna decided to repeat the above Higher Training Course, and as of 2008-2009 partnerships have been set up with University of Messina, University of Roma "La Sapienza" and University of Verona.

Right through from 2007-2008 to 2009-2010, Bologna University also offered a Higher Training Course on "Sociology of Health and Non Conventional Medicines". In 2007-2008 the University of Napoli "Federico II" ran a Level-II Masters on "Acupuncture in muscle-skeleton pathology", while the University of Roma's "Tor Vergata" launched its first Level-II two-year Masters in "Non Conventional Medicines".

A common training policy is gradually spreading. In the academic year 2007-2008 each geographical area of Italy (North, Centre, South) provided post-graduate training in CAM, and every subsequent year has repeated the option.

From $22^{\text {nd }}$ to $25^{\text {th }}$ June 2009 the University of Milano ran the meeting "Natural Substances: back to the past or new opportunities?", while for the academic year 2009-2010 the University of Roma Rome "La Sapienza" put on a Level-I Masters in "Naturopathy".

Veterinary Science has in turn rallied to the call of new and/or traditional paradigms of treatment. For the academic year 2008-2009 the University of Milano proposed a Level-II Masters in "Veterinary Acupuncture" which eventually failed to run for bureaucratic reasons.

This brief and admittedly non-exhaustive historical panorama is enough to show that interest runs transversally across the geographical areas: a "fashion", sensibility or new way of seeing health has rapidly spread throughout Italy, at least in its macro areas (North, Centre, South).

\section{Post-graduate Education Options in Italy}

As this study and others in the past have shown, the official position 
Citation: Tognetti Bordogna M, Gentiluomo A, Roberti di Sarsina P (2013) Post-graduate Education in Traditional and Non Conventional Medicine: Italy poised between National Guidelines and Regional Variants. Altern Integ Med 2: 143. doi:10.4172/2327-5162.1000143

Page 3 of 8

of the Permanent Conference of Deans of Medicine Degree Courses is out of line with various universities' decisions.

Our survey of post-graduate training options found that 19 Masters (7 Level I, 12 Level II) and 10 Postgraduate Completion Courses were started up in the academic year 2011-2012.

No Higher Training Curses or PhDs in these traditional health areas were initiated, though mention must be made of "Clinical evidence for high-quality Phytotherapy preparations in gynaecology", a teaching module of the University of Torino PhD Programme in "Biomedical Sciences and Oncology".

There likewise prove to be no researchers, and no associate, extraordinary or ordinary professors specifically engaged in CAM.

The private universities still seem to be investing little in CAM training, even though doing so might be an eye-catching distinction on the national panorama [5].

\section{University Mastercourses}

"Level I and II Mastercourses, open respectively to 3-year and 5-year degree holders, are for a limited number of participants and require a tutor assisting the teaching staff. The aim is to provide professional knowledge and skills of a technical or planning kind. They are also open to professionals seeking forms of re-qualification. They consist in contact teaching hours, practicals, individual study and laboratory work, and they conclude with an internship. A university mastercourse confers an academic qualification and requires possession of at least 60 credits" [16].

In the academic year 2011-2012 seven universities Level-I Masters (Table 1) and 12 university Level-II masters (Table 2) were run in the field of TM/NCM education. That only $36.8 \%$ were Level-I Masters is because such advanced training, designed to produce health professionals, tends to recruit from 5-year degree holders, whether single-cycle or specialist.

An increase in training options is noted over the previous survey. Mastercourses go from 17 to 19 , an 11.8\% increase.

As shown in Figure 1, the Regions with universities that train by Masters in Traditional and Non Conventional Medicine continue to be the seven previously cited (Lombardia, Emilia Romagna, Toscana, Lazio, Campania, Sicilia and Sardegna). Again, one notes the exceptional zeal of Toscana and Lazio which together account for 58\% of the whole training menu-a 5\% step up from the previous finding [5].

\begin{tabular}{|l|l|l|l|}
\hline $\begin{array}{l}\text { Geographical } \\
\text { area }\end{array}$ & Region & $\begin{array}{l}\text { Universities and } \\
\text { faculties }\end{array}$ & Title of masters \\
\hline North & Lombardia & $\begin{array}{l}\text { Milano-bicocca faculty of } \\
\text { sociology and faculty of } \\
\text { medicine }\end{array}$ & $\begin{array}{l}\text { Health Systems, Traditional } \\
\text { and Non-Conventional } \\
\text { Medicines }\end{array}$ \\
\hline Centre & Toscana & Siena faculty of medicine & $\begin{array}{l}\text { Complementary medicines } \\
\text { and integrated therapies }\end{array}$ \\
\hline & Lazio & $\begin{array}{l}\text { Pisa faculty of medicine } \\
\text { Firenze faculty of } \\
\text { medicine }\end{array}$ & $\begin{array}{l}\text { Rostural Osteopathy } \\
\text { faculty of medicine }\end{array}$ \\
\hline Campania & $\begin{array}{l}\text { Napoli "federico ii" faculty } \\
\text { of medicine }\end{array}$ & Osteopathy \\
\hline South & Sicilia & $\begin{array}{l}\text { Palermo faculty of } \\
\text { medicine }\end{array}$ & $\begin{array}{l}\text { Clinical and therapeutic } \\
\text { applications of the } \\
\text { phytotherapy pharmacopoeia }\end{array}$ \\
\hline
\end{tabular}

Table 1: Level-I masters by region.

\begin{tabular}{|c|c|c|c|}
\hline $\begin{array}{l}\text { Geographical } \\
\text { area }\end{array}$ & Region & $\begin{array}{l}\text { Universities and } \\
\text { faculties }\end{array}$ & Title of masters \\
\hline North & $\begin{array}{l}\text { Emilia } \\
\text { romagna }\end{array}$ & $\begin{array}{l}\text { Bologna faculty of } \\
\text { medicine }\end{array}$ & $\begin{array}{l}\text { Traditional chinese medicine } \\
\text { with acupuncture, } \\
\text { homeopathic medicine, } \\
\text { medical phytotherapy }\end{array}$ \\
\hline \multirow[t]{7}{*}{ Centre } & \multirow[t]{3}{*}{ Toscana } & $\begin{array}{l}\text { Siena faculty of } \\
\text { pharmacy }\end{array}$ & Phytotherapy \\
\hline & & $\begin{array}{l}\text { Siena faculty of } \\
\text { pharmacy }\end{array}$ & Applied phytotherapy \\
\hline & & $\begin{array}{l}\text { Siena faculty of } \\
\text { medicine }\end{array}$ & Integrated medicine \\
\hline & \multirow[t]{4}{*}{ Lazio } & $\begin{array}{l}\text { Roma "la sapienza" } \\
\text { faculty of pharmacy } \\
\text { and medicine }\end{array}$ & $\begin{array}{l}\text { "acupuncture-phytotherapy } \\
\text { (integration of traditional } \\
\text { chinese medicine and } \\
\text { western medicine) }\end{array}$ \\
\hline & & $\begin{array}{l}\text { Roma "la sapienza" } \\
\text { faculty of medicine }\end{array}$ & Phytotherapy \\
\hline & & $\begin{array}{l}\text { Roma "la sapienza" } \\
\text { faculty of medicine } \\
\text { and psychology }\end{array}$ & $\begin{array}{l}\text { Integration of traditional chinese } \\
\text { medicine and western medicine }\end{array}$ \\
\hline & & $\begin{array}{l}\text { Roma "tor vergata" } \\
\text { faculty of medicine }\end{array}$ & Clinical acupuncture \\
\hline \multirow[t]{4}{*}{ South } & \multirow[t]{2}{*}{ Campania } & $\begin{array}{l}\text { Napoli "federico ii" } \\
\text { faculty of medicine }\end{array}$ & $\begin{array}{l}\text { Acupuncture and traditional } \\
\text { chinese medicine in } \\
\text { gynaecology and obstetrics }\end{array}$ \\
\hline & & $\begin{array}{l}\text { Napoli "federico ii" } \\
\text { faculty of medicine }\end{array}$ & $\begin{array}{l}\text { Acupuncture in } \\
\text { muscular-skeletal pathologies }\end{array}$ \\
\hline & Sicilia & $\begin{array}{l}\text { Messina faculty of } \\
\text { medicine }\end{array}$ & Non-conventional medicines \\
\hline & Sardegna & $\begin{array}{l}\text { Sassari faculty of } \\
\text { medicine }\end{array}$ & Antalgic acupuncture \\
\hline
\end{tabular}

Table 2: Level-II masters by region.

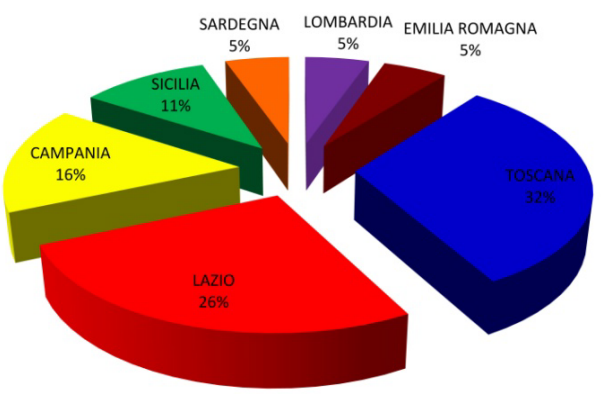

Figure 1: Offerta di Master distinta per Regione.

Tuscany has overhauled Lazio in the number of academic institutes providing TM/NCM education. It is the only Italian region geared to including TM/NCM in its regional health system [6].

\section{Professional Postgraduate Completion Courses in TM/ NCM}

When it comes to Postgraduate Completion Courses, more Regions are offering university education. A Postgraduate Completion Course is training reserved for a limited number of attendees, "an in-depth scientific update, an ongoing and recurrent refresher experience developing and honing high-level skills with a view to enhancing professionalism. In this case the university issues a simple certificate of attendance and lists the skills acquired" [28] (Figure 2 and Table 3).

Compared with the previous survey [5], there is a distinct increase in Upgrade Course options. The number goes from 5, as proposed by the Medical Faculty, to 10 -a $100 \%$ increase. It is the Pharmacy Faculties 
Citation: Tognetti Bordogna M, Gentiluomo A, Roberti di Sarsina P (2013) Post-graduate Education in Traditional and Non Conventional Medicine: Italy poised between National Guidelines and Regional Variants. Altern Integ Med 2: 143. doi:10.4172/2327-5162.1000143

Page 4 of 8

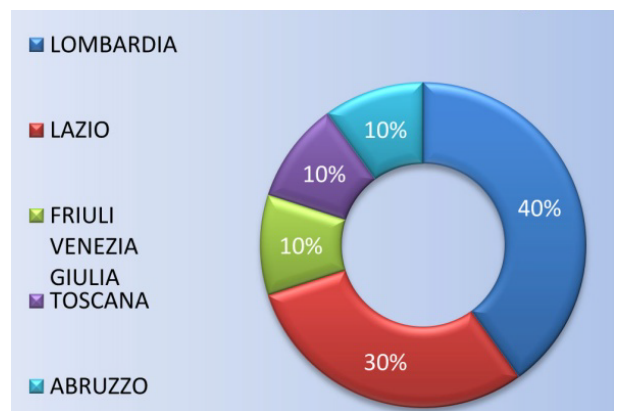

Figure 2: The ten postgraduate completion courses in five regions.

\begin{tabular}{|c|c|c|c|}
\hline $\begin{array}{l}\text { Geographical } \\
\text { area }\end{array}$ & Region & $\begin{array}{l}\text { Universities and } \\
\text { faculties }\end{array}$ & Title of upgrade course \\
\hline \multirow[t]{5}{*}{ North } & $\begin{array}{l}\text { Friuli venezia } \\
\text { giulia }\end{array}$ & $\begin{array}{l}\text { Trieste-faculty of } \\
\text { pharmacy }\end{array}$ & Phytotherapy \\
\hline & \multirow[t]{4}{*}{ Lombardia } & $\begin{array}{l}\text { Milano-faculty of } \\
\text { medicine }\end{array}$ & $\begin{array}{l}\text { Non conventional } \\
\text { medicines and } \\
\text { complementary techniques } \\
\text { (3-years module). }\end{array}$ \\
\hline & & $\begin{array}{l}\text { Milano-faculty of } \\
\text { medicine }\end{array}$ & $\begin{array}{l}\text { Biological regulation } \\
\text { and complementary } \\
\text { medicines }\end{array}$ \\
\hline & & $\begin{array}{l}\text { Milano-faculty of } \\
\text { medicine }\end{array}$ & $\begin{array}{l}\text { Acupuncture-stress and } \\
\text { related pathology }\end{array}$ \\
\hline & & $\begin{array}{l}\text { Brescia-faculty of } \\
\text { medicine }\end{array}$ & $\begin{array}{l}\text { Acupuncture and related } \\
\text { techniques }\end{array}$ \\
\hline \multirow[t]{5}{*}{ Centre } & Toscana & $\begin{array}{l}\text { Siena-faculty of } \\
\text { pharmacy }\end{array}$ & Phytotherapy \\
\hline & Abruzzo & $\begin{array}{l}\text { Pescara-chieti-faculty of } \\
\text { medicine }\end{array}$ & Biointegrated medicine \\
\hline & \multirow[t]{3}{*}{ Lazio } & $\begin{array}{l}\text { Viterbo "Tuscia"-faculty } \\
\text { of pharmacy }\end{array}$ & $\begin{array}{l}\text { Phytotherapy and herbs } \\
\text { level I }\end{array}$ \\
\hline & & $\begin{array}{l}\text { Viterbo "Tuscia"-faculty } \\
\text { of pharmacy }\end{array}$ & $\begin{array}{l}\text { Clinical phytotherapy } \\
\text { level II }\end{array}$ \\
\hline & & $\begin{array}{l}\text { Viterbo "Tuscia"-faculty } \\
\text { of pharmacy }\end{array}$ & $\begin{array}{l}\text { Herbs and applied } \\
\text { phytotherapy level-III }\end{array}$ \\
\hline
\end{tabular}

Table 3: Postgraduate completion courses.

that are particularly interested in gaining other specialists or health workers and deepening CAM education.

Though progress in Postgraduate Completion Courses is 'cautious', the trend is promising for the future of educational accreditation and the acknowledgment that these anthropological healing systems work. One notes that the five new Postgraduate Completion Courses are all in Phytotherapy, which has an illustrious research tradition in Toscana.

There is also a change in the distribution of training Masters. More regions have come in (Friuli Venezia Giulia, Toscana e Lazio), and the previously documented superiority of the North [5] has been levelled. Whereas the North and Centre of Italy invest equally in this postgraduate training, the South continues to be devoid of such ventures.

Lombardia remains the most 'virtuous' region, accounting for $40 \%$ of the range on offer, followed by Lazio on $30 \%$, where University of Tuscia (Viterbo) is a pioneer in promoting TM/NCM.

University of Milano, previously leader in TM/NCM Postgraduate Completion Courses, is now first-equal with University of Tuscia (Viterbo). Both offer 30\% of the training here. Of course, there is an obvious difference between laying on a Masters or an Upgrade Course: the former carries a full-blown study qualification, the latter only a certificate. Running a Masters may thus imply a greater, more informed commitment to TM/NCM; but the increase in Postgraduate Completion Courses does confirm the mounting involvement of universities in TM/NCM education, in line with the growing demand for TM/NCM treatment throughout Italy and elsewhere [29].

\section{What forms of TM/NCM Dominate the Post-graduate Scene?}

Although certain Masters have a particular TM/NCM slant, if one analyses the titles proposed by the Faculties we considered, it becomes clear that the greatest accreditation and hence education kudos is enjoyed by Phytotherapy and Acupuncture which respectively account for $34.5 \%$ and $27.6 \%$ of all education options.

One of the reasons for the great interest in Phytotherapy is the long-standing herbalist tradition in Italy. Here the research centre in Toscana conforms to western standards, manufacturing processes and research into plant product effectiveness. Outside stakeholders, like pharmaceutical firms, are also interested. The practice enjoys greater credit than Acupuncture, having many PubMed publications to its name, especially (but not only) in the treatment of headache; again, the approach is more functional and more similar to western allopathic medicine; and indeed, this kind of therapy has found its way into various regional health systems. "For its part, acupuncture is freely prescribed at certain important health centres like Sant'Anna Hospital in Torino. One also notes with interest how the focus is on Acupuncture and not Traditional Chinese Medicine, of which it is only one form of application, along with Qi Gong, diet, Tuina, Moxa and Chinese Phytotherapy" [26-28]

One is bound to point out that the two post-graduate education courses: "Traditional Chinese Medicine with acupuncture, Homeopathic Medicine, Medical Phytotherapy" at University of Bologna and "Acupuncture-Phytotherapy (Combining Traditional Chinese Medicine with Western Medicine) at University "La Sapienza" in Roma-entails both acupuncture and phytotherapy, and is reckoned as double in our data.

$\mathrm{TM} / \mathrm{NCM} / \mathrm{CAM}$ in university education is thus on a more limited scale than TM/NCM/CAM options in health nationwide.

\section{Choosing Titles for Post-graduate Courses}

Another side to our analysis concerns the title chosen to describe the Masters or Upgrade Course.

Titles range from specific, applicative nomenclature, referring to one or more CAM, to more generic, simpler, inclusive or concise titles. We grouped the 29 titles under three categories.

\section{TM/CAM (11 post-grad courses)}

These include Masters in "Phytotherapy", "AcupuncturePhytotherapy (Combining Traditional Chinese Medicine with Western Medicine)"; "Traditional Chinese Medicine with Acupunture, Homeopathic Medicine, Medical Phytotherapy"; "Osteopathy"; "Combining Traditional Chinese Medicine with Western medicine" (6 Masters); and Postgraduate Completion Courses in "Phytotherapy", "Phytotherapy and herbs", "Clinical Phytotherapy", "Acupuncture and related techniques” (5 Upgrades).

\section{Clinical application of TM/CAM (9 post-grad courses)}

These include: "Clinical and Therapeutic Applications of the Phytotherapy Pharmacopeia"; "Clinical Acupuncture"; "Postural 
Citation: Tognetti Bordogna M, Gentiluomo A, Roberti di Sarsina P (2013) Post-graduate Education in Traditional and Non Conventional Medicine: Italy poised between National Guidelines and Regional Variants. Altern Integ Med 2: 143. doi:10.4172/2327-5162.1000143

Osteopathy"; "Acupuncture and Traditional Chinese Medicine in Gynaecology and Obstetrics"; "Antalgic Acupuncture"; "Acupuncture in muscle-skeleton pathology"; "Applied Phytotherapy" (7 Masters); and Postgraduate Completion Courses in "Acupuncture - Stress and Related Pathology" and "Herbs and Applied Phytotherapy"(2 Upgrades).

\section{Cluster courses (8 post-grad courses)}

These include: "Complementary medicines and integrated therapies"; "Natural Medicine"; "Natural Medicines"; "Integrated Medicine"; "Non Conventional Medicines" (5 Masters) and Postgraduate Completion Courses in "Non Conventional Medicines and Complementary Techniques (3-year module)", "Biological Regulation and complementary medicines" and "Biointegrated Medicine" (3 Upgrades).

The Mastercourse in "Health Systems, Traditional and Non Conventional Medicine" offered by University of Milano-Bicocca is a case apart. This enlists the Faculties of Sociology and Medicine together with the Italian Charity Association for Centred Medicine; its title conveys the idea of introducing CAM into Regional Health Systems $[1,2]$. Part of its focus is indeed on comparative health systems and the title, which brackets Traditional Medicine with Non Conventional Medicine, hints at integration and above all the introduction of forms of TM/NCM as efficient in their own right and a possible ally to western medicine. The aim of this Masters is also to create the profile of Manager of "Health Systems, Traditional and Non Conventional Medicine" equipped with interdisciplinary skills fit for inclusion in the Health System (whether national or regional). This suggests the broader concept of the Pro-Health System: management of new-style health, able to combine TM/NCM/CAM with other forms of medicine.

In the first group TM/CAM, the titles contain the name of the CAM areas the Masters or Upgrade Course is based on. The name itself attracts participants and lends the course authority. It somehow suggests confidence, esteem for the intrinsic value of such medicines, and scope for combining them with western biomedicine. Acupuncture and Phytotherapy lead the field-clear direct titles.

In the second group, Clinical application of TM/CAM, the need seems to be to hook CAM onto specific practices so as to increase their scientific profile, suggesting more legitimacy and hence effectiveness. The title betrays a need to "westernise" CAM so as to court participant interest.

The last group of Cluster courses shows a quite different situation, a name that is a peg on which to hang CAM. Within the syllabus there may be a common part and then different specialisations, allowing participants to re-attend the Masters and specialise in its various specialist branches. Such Masters and Postgraduate Completion Courses offer a generic training in CAM. But the group does make one think about how we use the term CAM.

The first question here is whether to use the singular or plural form (Medicine or Medicines). The second concerns the adjective employed with it: natural, non conventional, integrated, complementary, integrative, etc. As stated in the introduction, CAM stands for Complementary and Alternative Medicine. In the cases in point, the concept of 'alternative' may be replaced by 'non conventional. This occurs twice, while only one Masters uses the adjective 'complementary'. The emphasis is probably on the idea of 'integrated' and 'natural. The former assumes a necessary synergy between western biomedicine and eastern TM, though as a term it may be misunderstood. The latter refers to a value, that of being natural, which can be relied on to have an impact on the market. Semantically 'natural' stands opposed to 'cultural', raising the age-old issue that has so reverberated in sociology and anthropology [30-35]. TM/NCM/CAM is defined as certain natural medicine in that: they belong to the history of humanity; they are practices and remedies springing from observation and the earth; they include the human being in all his aspects and seek to treat the person and not the disease; they may trace the cause of the 'complaint' to a non-physical plane; they rest on the principle of 'do no harm' and avoid vaccines or synthetic drugs, for example, which may prove counterproductive to the system; they seek to cultivate healthy lifestyles and the ideas of prevention and building up the immune system, etc. 'Cultural' assumes peculiar meanings according to the context, but here ties up with the technological and scientific side, observation of symptoms, focus on the part at the risk of losing sight of the whole (ö $\lambda$ oc) $[19,21]$. Such thinking even prompts a distinction between medicine seen as art and medicine seen as science (technique).

The distribution of titles in Figure 3 shows a preference for direct immediate reference to anthropological know-how as the object of training. The attitude springs from a desire for clarity and completeness in relation to one of the 8 Traditional and Non Conventional Medicines considered.

\section{Regional trends in training options}

Regional analysis of university training in CAM produces an interesting tie-up with specific regional health models $[14,22,23]$ and the way regional health service management skills are structured (Table $4)$.

It emerges from this breakdown that 9 Italian regions out of 20 contain universities that provide post-graduate education in CAM.

As many as 3 out of the 5 special-statute regions (Friuli Venezia Giulia, Sardegna, Valle d'Aosta, Trentino-Alto Adige and Sicilia) possess education centres that are sensitive to CAM education. The fact

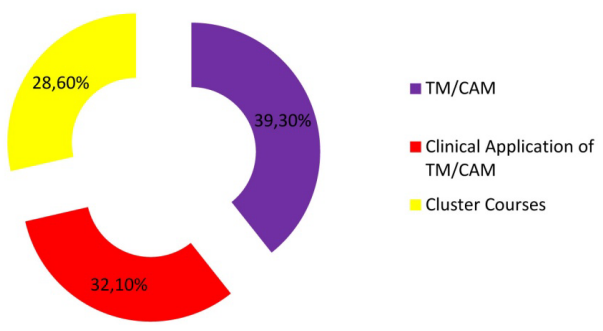

Figure 3: Different TM/CAM education groups.

\begin{tabular}{|l|c|c|c|}
\hline Region & $\begin{array}{c}\text { Number of } \\
\text { masters }\end{array}$ & $\begin{array}{c}\text { Number of } \\
\text { postgraduate } \\
\text { completion courses }\end{array}$ & Total on Offer \\
\hline Friuli Venezia Giulia & 1 & 1 & 1 \\
\hline Lombardia & 1 & 4 & 5 \\
\hline Emilia Romagna & 6 & 1 & 1 \\
\hline Toscana & & 1 & 7 \\
\hline Abruzzo & 5 & 3 & 1 \\
\hline Lazio & 3 & & 3 \\
\hline Campania & 2 & & 2 \\
\hline Sicilia & 1 & 10 & 1 \\
\hline Sardegna & 19 & & 29 \\
\hline Total & & & 8 \\
\hline
\end{tabular}

Table 4: Post-graduate education in traditional and non conventional medicine. 


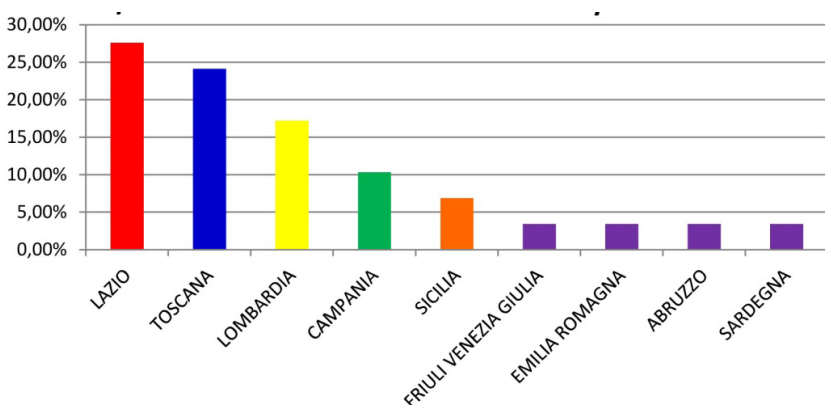

Figure 4: TM/CAM post-graduate education by regions.

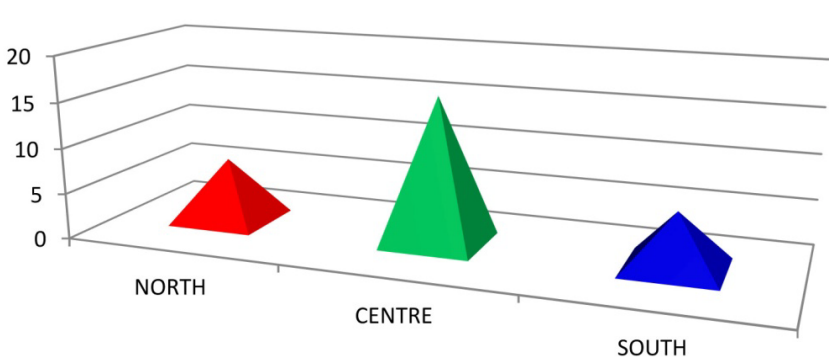

Figure 5: Post-graduate education options in TCAM by Italian geographical area.

\begin{tabular}{|l|}
\hline ISTAT (1996-99) \\
\hline ABACUS (2003) \\
\hline DOXA (2003) \\
\hline ISPO (2003) \\
\hline FORMAT (2003) \\
\hline CENSIS (2003) \\
\hline Menniti-Ippolito et al. (2004) \\
\hline ISTAT (2005) \\
\hline EURISPES (Rapporto Italia 2006) \\
\hline $\begin{array}{l}\text { Osservatorio Scienza Tecnologia e Società, Centro Ricerche } \\
\text { Observa-Science in Society, Nova II Sole 24 Ore 24 07.12.2006 }\end{array}$ \\
\hline CENSIS (2008) \\
\hline EURISPES (Rapporto Italia 2010) \\
\hline Health Monitor CompuGroup Medical-II Sole 24 Ore Sanità (2011) \\
\hline EURISPES (Rapporto Italia 2012) \\
\hline Doxapharma (2012) \\
\hline
\end{tabular}

9 million Italians use NCM (15.5\%)

$30 \%$ of Italians are familiar with the term Non-Conventional Medicine

$23 \%$ of the population use NCM

$65 \%$ of the population are familiar with the term Non-Conventional Medicine and know something about it $31.7 \%$ of Italians have used NCM at least once; $23.4 \%$ use NCM regularly

$50 \%$ think NCM useful; over $70 \%$ claim it should be passed by the National Health Service; $65 \%$ would like more monitoring by the national health authorities

3-year follow-up on 52,332 families (140,011 persons): $15.6 \%$ use NCM (homeopathy $8.2 \%$, manual therapy $7 \%$, phytotherapy $4.8 \%$, acupuncture $2.9 \%$, other NCMs $1.3 \%$ )

8 million Italians use NCM $(13.6 \%$ of the population)

$10.6 \%$ of the population choose NCM

One Italian out of three adopted, at least occasionally, homeopathic medicinal products to cure and treat illnesses.

$23.4 \%$ had adopted to $\mathrm{TM} / \mathrm{NCM}$ medication therapies and non-medication therapies in the previous year (especially homeopathy and phytotherapy)

more than 11 million opt for NCM medication therapies and non-medication therapies, i.e. $18.5 \%$ of the population

About $52 \%$ of general practitioners suggest homeopathic therapies to patients

$14.5 \%$ of the population adopt NCM

$82.5 \%$ declare to have been informed about homeopathic medicinal products; $16.2 \%$ adopted, at least once in the year, homeopathic medicinal products.

Table 5: Use of Traditional and Non-Conventional Medicine in Italy 1996-2012 [updated from Roberti di Sarsina P, Iseppato I. (2011) EPMA Journal, 2: 439-449].

is probably significant: these regions have their own forms of autonomy and, education-wise, may be drawn to different pathways of professional enhancement from other regions (Figure 4).

There proves to be a strong concentration by geographical area: Central Italy is definitely the trail-blazer. No less that 55.2\% of CAM training operations are provided by academic institutions in the centre of the country (Figure 5).

The outcome here reflects the numerical strength of University of Roma "La Sapienza" and the Universities in Toscana region, especially Siena.

Toscana stands confirmed as the strategically key area that has most taken to heart the issue of TM/NCM.

There is also a significant tie-up between Regional Health Systems that have shown interest in TM/NCM in the past and universities in those regions focusing on university education in that field [5]. Regions "like Lombardia and Toscana and even Campania that approve many sensitization and experimental projects, as well as creating specific bodies to study and monitor TM/NCM" [23], prove to be the very ones that are prominent for their high number of centres providing postgraduate education in TM/NCM. One must also add that Lazio Region is decisive in weighting the distribution bias towards Central Italy.

Our previous question thus remains open: Regions and Universities converging on this issue, or pure chance? One should not rule out the effect of the surrounding environment: where there is greater openmindedness about recourse to TM/NCM, as in Lombardia, or where Regional Health Systems are more inclined to TM/NCM, or where experiment is in progress [6], there is also an increase in the relevant university education. This may denote greater alignment of university training with the needs of the particular area, or at any rate some mutual influence between surrounding context and training institutes (Table 5).

\section{Conclusions}

The credibility of the anthropological healing traditions is gaining ground, involving universities and teachers, and attracting graduates who are more and more interested in such subjects. The University in its education schemes is perforce coming more into line with the new requirements and above all the demand from increasing swaths of patients who have the right to choose their therapy [36] and are turning to TM/NCM specialists- though in Italy, at least, the way of doing so varies from region to region $[37,38]$.

The University is in duty bound to ensure that specialists are able to meet the new treatment demand [39]; education must be standardised, and not left to the discretion of scientifically untrained or unauthorised people. Were this not so, there would be a risk of gross westernization of such practices and radical distortion of the principles they rest on. Our findings show that this policy is not shared by all university education centres across the country. 
Citation: Tognetti Bordogna M, Gentiluomo A, Roberti di Sarsina P (2013) Post-graduate Education in Traditional and Non Conventional Medicine: Italy poised between National Guidelines and Regional Variants. Altern Integ Med 2: 143. doi:10.4172/2327-5162.1000143

What emerges from our research is that things are on the move, every year new post-graduate courses are being run. In the academic year 2012-2013 we may cite the Level-I Masters in "Osteopathic Science" put on by University of Milano-Bicocca, University of Pavia’s Upgrade Course to form "Coordinators of integrated medicine" (which did not get off the ground in 2011-2012 through lack of enrolments), and University of Siena's 16-hour Professional Upgrade Course entitled "Full clinical-practical immersion in integrated medicine".

With such data as these, it is quite clear that the academic world is increasingly opening its doors to TM/NCM.

It is to be hoped that the University will work more and more to inform about and promote this field. It could be a forum facilitating networks by which otherwise isolated scholars and professionals can interact. One hopes it will go over to continuous education here, and invest in research to back it up. This will ensure that the TM/NCM world is scientific-an increasingly urgent need.

There are many possible avenues of education and information. Other countries, we see, are successfully experimenting with new forms of didactics and communications strategy; they are involving quite diverse experts sharing an interest in CAM research above all [40-45].

There is still a long way to go, but one glimpses a response to what is a steadily mounting demand for health and treatment.

\section{References}

1. Roberti di Sarsina P, Tognetti Bordogna M, Gensini GF (2012) A collaborative post-graduate educational project: the MasterCourse in "Health Systems, Traditional and Unconventional Medicine, European Journal of Integrative Medicine 4: 87

2. Roberti di Sarsina P, Tognetti Bordogna M (2012) An innovative post-graduate Master Course in Italy: "Health Systems, Traditional and Non Conventional Medicine". Poster presented at International Congress for Educators in Complementary and Integrative Medicine, Washington DC.

3. Lechi A, Vantini I (2004) Riflessioni sulle medicine alternative e complementar ed il Corso di Laurea Specialistica in Medicina e Chirurgia. Conferenza congiunta dei Presidi di Facoltà di Medicina e Chirurgia e dei Presidenti di Corso di Laurea Specialistica in Medicina e Chirurgia, Alghero, 2 maggio 2004. Medicina e Chirurgia 24:919-923.

4. Vantini I, Caruso C, Craxì A (2011) Conferenza Permanente dei President dei Corsi di Laurea in Medicina e Chirurgia. L'insegnamento delle Medicine Alternative e Complementari (CAM) nel Corso di Laurea Magistrale in Medicina e Chirurgia. Posizione della Conferenza Permanente dei Presidenti dei CLM. Genova 1 luglio 2011. Medicina e Chirurgia 53: 2331-2332.

5. Tognetti Bordogna M, Gentiluomo A, Roberti di Sarsina P (2013) Education in Traditional and Non Conventional Medicine: A Growing Trend in Italian Schools of Medicine, Altern Integ Med 2.

6. Tognetti Bordogna M (2011) Regional Health System and Non Conventional Medicine: The Situation in Italy, EPMA Journal, June 2011.

7. Vannacci A. Giovanardi CM, Geppetti P, Mugelli A, Gensini GF (2007) Modelli di integrazione a livello di didattica universitaria. In: Giarelli G, Roberti di Sarsina P, Silvestrini B, eds. Le Medicine Non Convenzionali in Italia. Storia, problemi e prospettive d'integrazione. Milan, FrancoAngeli 88-137.

8. Roberti di Sarsina P (2007) The Social Demand for a Medicine Focused on the Person: The Contribution of CAM to Healthcare and Healthgenesis. EvidenceBased Complementary and Alternative Medicine 4: 45-51.

9. Roberti di Sarsina P, Tognetti Bordogna M (2011) The need for higher education in the sociology of traditional and non-conventional medicine in Italy: towards a person-centered medicine, EPMA Journal 2: 357-363.

10. Roberti di Sarsina P, Gentiluomo A, Tognetti Bordogna M (2012) Education in Traditional and Unconventional Medicine in Italian Schools of Medicine. A content analysis and survey. European Journal of Integrative Medicine 4S:163.

11. Health Monitor. Diamo voce alle opinioni dei medici (2012) I quaderni di medicina, CompuGroup Medical-II Sole 24 Ore.
12. Rapporto Italia 2012. Sei dicotomie per capire I'Italia: vita/morte, essere/ avere, giustizia/ingiustizia, ragionevole/irragionevole, genitori/figli, sostenibile/ insostenibile. Eurispes, Roma.

13. Medicinali omeopatici e popolazione italiana. Doxapharma per Omeoimprese (2012) Omeoimprese, Milano.

14. Roberti di Sarsina P, Iseppato I (2009) Non Conventional Medicine in Italy: the present situation. European Journal of Integrative Medicine 1: 65-71.

15. Melucci A (1997) La libertà che cambia, Una ecologia del quotidiano. Milano, Unicopli.

16. Tognetti Bordogna M (1989) I confini della salute: paradigmi da contestualizzare Milano, FrancoAngeli.

17. Roberti di Sarsina P, Iseppato I (2011) Why we need integrative medicine, EPMA Journal 2: 5-7.

18. Colombo E, Rebughini $P$ (2003) La medicina che cambia, Le terapie non convenzionali in Italia. Bologna, II Mulino.

19. Roberti di Sarsina P, Alivia M, Guadagni P (2012) Traditional, Complementary and Alternative medical systems and their contribution to Personalisation Prediction and Prevention in Medicine - Person Centred Medicine, EPMA Journal 3:15.

20. Roberti di Sarsina P, Alivia M, Guadagni $P$ (2012) Widening the Paradigm in Medicine and Health: Person Centred Medicine as Common Ground of Traditional and Non Conventional Medicine, Healthcare Overview, Advances in Predictive, Preventive and Personalised Medicine 1: 335-353.

21. Mapelli V (2012) II sistema sanitario italiano. Bologna, II Mulino.

22. Vicarelli G (2010) Gli eredi di Esculapio. Medici e politiche sanitarie nell'Italia unita. Roma, Carocci.

23. Roberti di Sarsina P, Iseppato I (2011) Traditional and Non Conventiona Medicines: the Socio-anthropological and Bioethical Paradigms for PersonCentred Medicine, The Italian context. EPMA Journal 2: 439-449.

24. Roberti di Sarsina P, Iseppato I (2010) Person-Centred Medicine: Towards a Definition, Forschende Komplementärmedizin 17: 277-278.

25. Roberti di Sarsina P (2013) Education in Acupuncture in Italy: The Oldest Italian Private School of Acupuncture Adopts WHO Guideline. TANG International Journal of Genuine Traditional Medicine 3: 4.1-4.3.

26. Roberti di Sarsina P (2013) Italy and the Dialogue on Human Health between Traditional Chinese Medicine Culture and Western Medicine Culture (TCM Dialogue), Forschende Komplementärmedizin 20: 148-150.

27. Tognetti Bordogna M, Gentiluomo A, Roberti di Sarsina P (2013) L'offerta formativa di Medicine Tradizionali e Non Convenzionali nelle Facoltà di Medicina in Italia. Un trend in espansione, Advanced Therapies-Terapie d'avanguardia 2: 12-26.

28. Roberti di Sarsina P (2010) Le Medicine Non Convenzionali nel Programma d'Azione dell'Unione Europea in Materia di Salute: il Consorzio CAMbrella, La Medicina Biologica 2: 29-37.

29. Sciolla L (2007) Sociologia dei processi culturali. II Mulino, Bologna

30. Ariño Villarroya A (2000) Sociología de la cultura. La constitución simbólica de la sociedad. Editorial Ariel, Barcelona.

31. Griswold W (1997) Sociologia della cultura. II Mulino, Bologna.

32. Cuche D (2006) La nozione di cultura nelle scienze sociali. II Mulino, Bologna

33. Wallace RA, Wolf A (2000) La teoria sociologica contemporanea. II Mulino Bologna.

34. Ember CR, Ember M (2003) Antropologia culturale. II Mulino, Bologna.

35. Roberti di Sarsina P, Morandi A, Alivia M, Tognetti Bordogna M, Guadagni P (2012) Medicine Tradizionali e Non Convenzionali in Italia. Considerazioni su una Scelta Sociale per la Medicina Centrata sulla Persona. Advanced Therapies-Terapie d'Avanguardia 1: 3-29.

36. Roberti di Sarsina P, Iseppato I (2010) State of art of the regulative situation of Non Conventional Medicines in Italy. The Journal of Alternative and Complementary Medicine 16: 141-142.

37. Roberti di Sarsina P, Iseppato I (2011) Non Conventional Medicine within the 
Citation: Tognetti Bordogna M, Gentiluomo A, Roberti di Sarsina P (2013) Post-graduate Education in Traditional and Non Conventional Medicine: Italy poised between National Guidelines and Regional Variants. Altern Integ Med 2: 143. doi:10.4172/2327-5162.1000143

Page 8 of 8

Italian Medical Profession. Poster presentation n. 172. 4th European Congress for Integrative Medicine, Berlin.

38. Roberti di Sarsina P (2005) 43rd National Congress of the Italian Psychiatric Association. Consensus Conference: Non-Conventional Medicines. EvidenceBased Complementary and Alternative Medicine 2: 233-235.

39. Rampes H, Sharples F, Fisher P (1997) Complementary Medicine in the Medical Curriculum, Journal of The Royal Society of Medicine 90: 357

40. Hill F. J. (2003) Complementary and Alternative Medicine: the Next Generation of Health Promotion? Health Promotion International 18: 265-272.

41. Levine SM, Weber-Levine ML, Mayberry RM (2003) Complementary and
Alternative Medical Practices: Training, Experience, and Attitudes of Primary Care Medical School Faculty, Journal Am Board Fam Pract 16: 318-326.

42. Varga O, Marton S, Molnar P (2006) Status of Complementary and Alternative Medicine in European Medical Schools, Forschende Komplementärmedizin 3 : 41-45.

43. Amri H, Haramati A, Sierpina VS, Kreitzer MJ (2012) Georgetown University's Graduate Program in Complementary and Alternative Medicine: Training Future Practitioners of Integrative Healthcare, Explore 8: 258-261.

44. Robinson N, Lewith G (2009) The RCCM 2009 Survey: Mapping Doctoral and Postdoctoral. CAM Research in the United Kingdom, Evid Based Complement Alternat Med. 